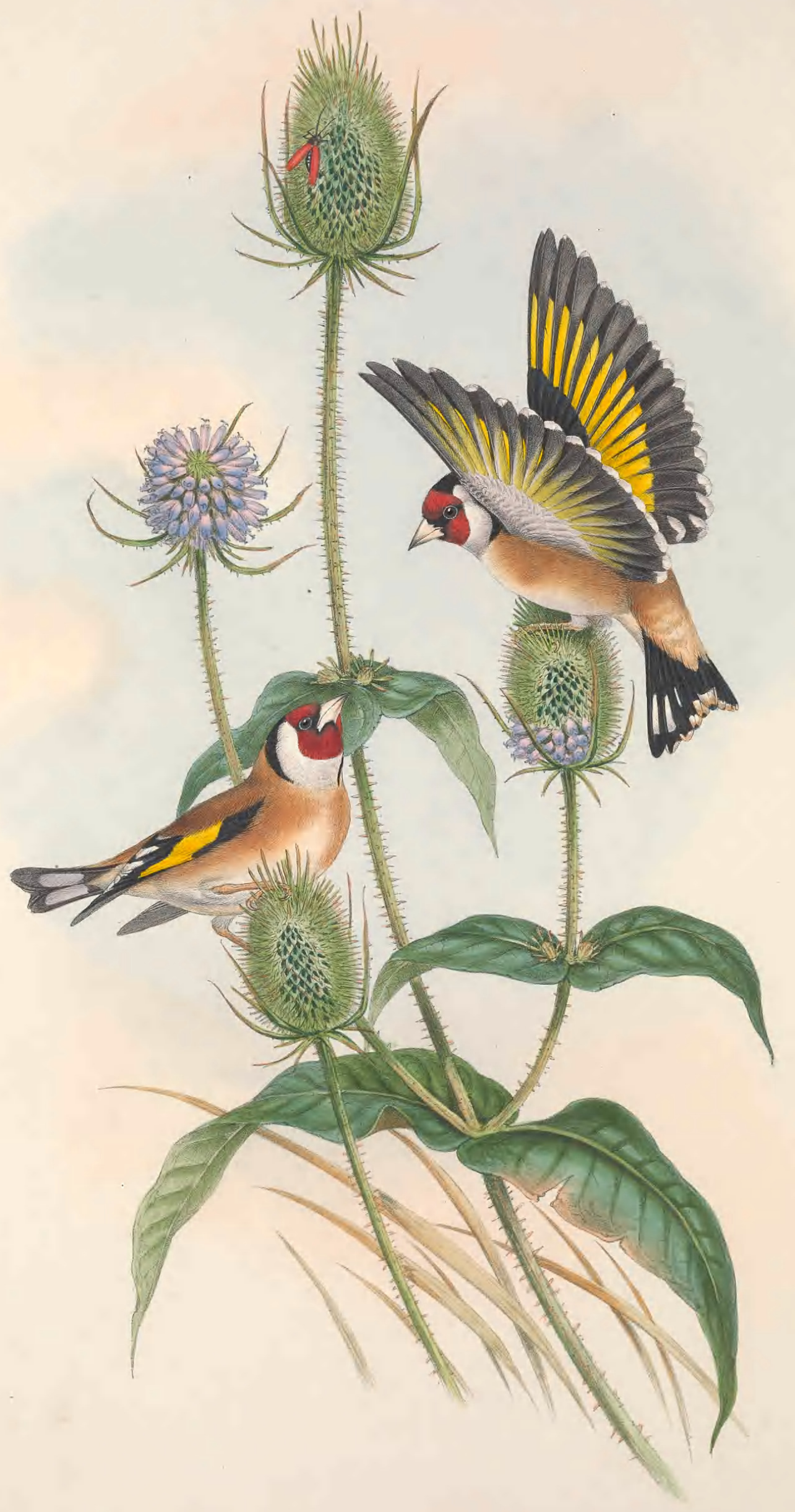




\section{CARDUELIS ELEGANS.}

Goldfinch.

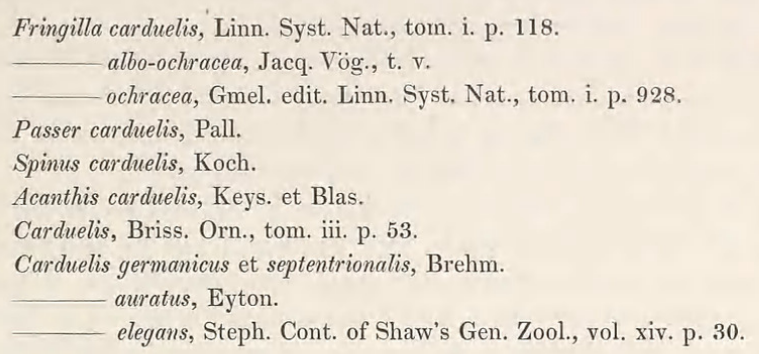

It has been asserted that there are many persons who have made the circuit of the globe without taking the least interest in the wonders and novelties which surrounded them. Such persons would doubtless look with equal vacancy from the window of a railway-carriage, without caring to know or perceiving the occupation of yonder man who is buffeting his hands at daybreak on a November morning, when the hoar frost has covered the ground with a silvery rime. That man, who stands in the middle of Wormwood Scrubs, or in a deserted brick-field a little further on, is the Whitechapel bird-catcher, engaged in his daily calling. $\mathrm{He}$ must have risen early, for he has trudged by lamplight through the streets of London, carrying his nets and cages on his back, and is now in the country, where he welcomes the rising of the sun, and awaits the flight of the Goldfinch. If the passing train should send the flock up from the sides of the deep cutting, the challenge of the call-bird will be heard and responded to, and after a few gyrations in the air and exchanges of voice, they will settle on the bunch of thistles or by the side of the call-bird between the nets. Foolish birds! your inquisitiveness has made you prisoners. Hitherto you have enjoyed freedom, you have breathed the purest of atmospheres; you have shared with the donkey the most cherished parts of the thistle; you have poured forth your twittering and pleasing song to the freest of men, for the dwelling of the gipsy has been in the midst of your feeding-grounds. You will now have to struggle for life in an air charged with impurities; no more flights over heaths and upland commons will you enjoy; never will you again build among the apple-blossoms of the cottager's garden : a cage, so small that you will be unable to flutter your wings, will be your prison, and the noise of the shuttle will be the response to your song. Still you will be well treated, for it is not in the nature of the weaver, or indeed of any one, to act otherwise to so pretty a bird; it is your beauty and the charms of your voice that have encaged you, and which, surpassing those of your companions the Greenfinch and the Linnet, renders them less in request.

How vast must be the numbers annually captured of this bird may be inferred from a passage in Mayhew's 'London Labour and London Poor,' which states that $\mathbf{2 0 0}$ persons gain a livelihood by capturing Goldfinches, Linnets, and other birds, which in nearly every instance are sold to the metropolitan poor. I know no taste more commendable than a love for natural objects; and whether this be bestowed upon birds or flowers, the family which can find enjoyment in such things are amongst the happiest of their class. Besides the numbers that are captured by means of ground-nets, many Goldfinches are obtained by other artifices, and thousands of the young birds are taken from the nests, or immediately after they have flown. These bald pates or branchers, as they are called, all or nearly all find their way to the London birddealers; and you have only to pass through one of the principal streets of Seven Dials, about the end of June, to satisfy yourself that this is the case. Commercially speaking, the traffic in Goldfinches must be something great; for although the bird-catchers get only two shillings and sixpence or three shillings a dozen, the amount of money exchanged between the retailers and the public must be very considerable, especially when we take into consideration that the traffic is not confined to London, but is carried on, though of course to a less extent, in most of the great towns of England.

With us the Goldfinch is a stationary bird; still great accessions to the numbers of those always resident in this country arrive from the Continent. Every observer of nature who resides on the Sussex coast will tell you that Goldfinches arrive in considerable numbers from the south during their vernal flights in March or April, and that these foreign birds are larger and finer than those bred in the neighbourhood of London. Whence have this race come? and to what locality are they proceeding? are questions not easily answered.

After the breeding-season is over, the Goldfinches roam about in companies of from eight to ten in 
number, and sometimes assemble in small flocks. They now affect open upland districts, commons, sterile wastes, and all situations suited to the growth of their favourite thistle, groundsel, and plantain. This food, however, is not suitable for the young, and they are accordingly fed with caterpillars and other insects ; hence considerable good must be effected by these birds during the breeding-season.

Independently of the British Islands, over which the bird is generally distributed, the Goldfinch inhabits all parts of the Continent, from Norway, Sweden, and Russia to the Mediterranean and Black Seas ; it is also found in Northern Africa, Asia Minor, and Persia, but not in India, its place there, or rather in the Himalayas, being supplied by another and equally interesting species, the Carduelis caniceps.

The history of the Goldfinch would be incomplete without an allusion to its capacity for receiving instruction, and the consequent readiness with which it may be taught many amusing tricks, such as drawing up water for itself, raising the lid of a small box to obtain the seeds within, feigning death, \&c. I have already spoken of its prettiness, and I may add that its colouring is both harmonious and beautiful; its form also is graceful, elegant, and well-proportioned; the Goldfinch is, in fact, the gay gentleman of our smaller birds. In most instances where much decoration is given, it is usually confined to the male; but in the present case the two sexes are nearly alike.

Speaking of the Goldfinch in Scotland, Macgillivray states that it is "generally distributed in most of our wooded and cultivated districts; but while plentiful in some parts, it is rare in others that seem to be equally favourable. Thus, although not uncommon about Aberdeen and Elgin, it is very rare in the neighbourhood of Edinburgh, in which I never met with more than a single flock." This statement is confirmed by the following note, with which I have been favoured by the Duke of Argyll :- "The Goldfinch is a rare bird in Dumbartonshire; but small parties are seen during the winter at uncertain intervals. In Argyleshire it is wholly absent, so far as I have observed, in the more wooded and in the more mountainous districts ; but it is not uncommon, and appears regularly to breed, along some of the lower western shores. I have observed young birds, in considerable numbers, in the Ross of Mull."

The nest of the Goldfinch is placed indifferently among the trees of orchards, gardens, and plantations, at various heights, according to the suitability of the sites that occur, sometimes among the very topmost branches. A very beautiful nest, taken at Formosa, near Cookham, in Berkshire, in July 1860, was placed on one of the loftiest branches of a tall sycamore, and was curiously interwoven between the slender forks of the extremity of the branch; the interior was deep, the walls somewhat thick, and the whole presented a round and compact appearance. The exterior was mainly composed of one or two different kinds of bright green lichens, firmly interwoven with dried moss and spiders' webs; the interior was warmly lined with the downy cotton-like substance of the blossoms of the willow, intermingled with wool and a very few horsehairs, the three ingredients being felted together, so as to render it perfectly smooth and even. The eggs, four in number, were of a pale greenish stone-colour, somewhat faintly blotched with light reddish purple, the blotches becoming more numerous towards the larger end, and having among them a few very distinct patches of rich umber. The materials of the nest appear to vary considerably. One of two, formerly in the possession of the late T. C. Heysham, Esq., of Carlisle, was externally composed of dried bent grasses, interwoven with lichens, moss, and wool, beantifully lined with thistle-down and a few very fine hairs; the other was mainly formed of roots instead of grasses, and had a few feathers in its lining, besides the thistledown and hair. Mr. Macgillivray describes the nest as resembling that of the Chaffinch in form, but as being more elaborately interwoven with wool and hair,- the exterior being composed of moss and lichens, and occasionally thread, twigs, and other substances; the interior, of the down of various plants, cotton, and such other delicate filaments as the bird meets with. Mr. Salvin mentions that at Djendeli, in the Eastern Atlas, the Goldfinch builds a neat nest, composed almost entirely of the flowers of the tamarisk.

The plumage of the adult male and female are so accurately represented in the accompanying Plate, that it will not be necessary to append a minute description of them. The young birds of the year have the whole of the head, neck, back, and sides of the chest of a nearly uniform greyish brown; in other respects they resemble the female; the black of the head begins to appear about the middle of September, and the red towards the end of that month.

The two sexes are figured, of the natural size, on the Wild Teasel (Dipsacus sylvestris). 


\section{$2 \mathrm{BHL}$ Biodiversity Heritage Library}

Gould, John. 1873. "Goldfinch, Carduelis elegans [PI. 36]." The birds of Great Britain 3, -. https://doi.org/10.5962/p.323927.

View This Item Online: https://www.biodiversitylibrary.org/item/221726

DOI: https://doi.org/10.5962/p.323927

Permalink: https://www.biodiversitylibrary.org/partpdf/323927

\section{Holding Institution}

Smithsonian Libraries

\section{Sponsored by}

Biodiversity Heritage Library

\section{Copyright \& Reuse}

Copyright Status: Public domain. The BHL considers that this work is no longer under copyright protection.

This document was created from content at the Biodiversity Heritage Library, the world's largest open access digital library for biodiversity literature and archives. Visit BHL at https://www.biodiversitylibrary.org. 